\title{
Morphology tuning of CoMo catalysts: Effect of La and Fe as an additive
}

\author{
Pei YU, Ming KE ${ }^{a}$, Qiang LIU , Xi Ming YAN \\ College of Science, China University of Petroleum-Beijing, 102249 Beijing, China
}

\begin{abstract}
Three catalysts $\mathrm{CoMo} / \gamma-\mathrm{Al}_{2} \mathrm{O}_{3}, \mathrm{CoMo}-\mathrm{La} / \gamma-\mathrm{Al}_{2} \mathrm{O}_{3}, \mathrm{CoMo}-\mathrm{Fe} / \gamma-\mathrm{Al}_{2} \mathrm{O}_{3}$ with different morphologies were prepared for study the effect of introduction of $\mathrm{La}$ and $\mathrm{Fe}$ on morphology properties and hydrodesulfurization (HDS) activity. The morphology properties of catalysts were characterized by BET, XPS and HRTEM. In addition, the catalytic performances of catalysts were investigated. The results indicated that the introduction of $\mathrm{La}$ and $\mathrm{Fe}$ promoted the sulfidation of Mo species and made the average length and stacking layer numbers of $\mathrm{MoS}_{2}$ slabs longer and higher. These effects could improve the activity of catalysts for HDS. The present results indicated that the catalyst modified by Fe had the best HDS activity with the optimal morphology among three catalysts.
\end{abstract}

\section{Introduction}

The production of clean gasoline has received considerable attention with the growing awareness of environmental protection. Hydrodesulfurization (HDS) as a key technique to produce clean gasoline is widely used in refineries. Therefore, numerous studies have focused on developing catalysts with high selective HDS performances $[1,2]$.

It is well known that the morphology properties of catalyst are closely related to their catalytic performances. Topsøe et al [3] reported that two kinds of CoMoS structure are formed during sulfuration process. Type I CoMoS structure exhibits low HDS activity, which has strong interaction with support. Type II CoMoS phase shows high HDS activity, which has weak interaction with support. So, more type II CoMoS phase can be formed via weaking interaction of metal and support with maintaining metal dispersion [4]. According to the Brimedge model [5], the $\mathrm{MoS}_{2}$ phase exist brim and edge active sites. Both HDS and hydrogenation of olefin (HYDO) reaction are catalyzed by the brim sites, while only HDS reaction occurs at the edge sites. The adjustment of interaction of metal and support could control the morphology of metal sulfide with changing the ratio of brim sites to edge sites.

Many studies have focused on the nature of support which is one of major factors affecting the morphology of active metal phase. The supports incorporated with $\mathrm{K}$, $\mathrm{Mg}, \mathrm{B}, \mathrm{P}$ and $\mathrm{Zr}$ has adjusted the morphology and dispersion of active metal phase, leading to the change of selective HDS performance $[6,7,8,9,10]$.

\footnotetext{
a Corresponding author: keming698@sohu.com
}

\section{Experimental}

\subsection{Materials}

The supports modified by La and Fe were prepared by incipient wetness impregnation of $\gamma-\mathrm{Al}_{2} \mathrm{O}_{3}$ (specific surface area $315.4 \mathrm{~m}^{2} / \mathrm{g}$; volume of pores $0.55 \mathrm{ml} / \mathrm{g}$; average pore diameter $6.96 \mathrm{~nm}$ ). Then, the resulting supports dried at $100{ }^{\circ} \mathrm{C}$ for $6 \mathrm{~h}$ and calcined at $550{ }^{\circ} \mathrm{C}$ for $4 \mathrm{~h}$. CoMo catalysts were prepared by co-impregnation of $\mathrm{La} / \gamma-\mathrm{Al}_{2} \mathrm{O}_{3}$ and $\mathrm{Fe} / \gamma-\mathrm{Al}_{2} \mathrm{O}_{3}$ using incipient wetness impregnation method, and then dried at $100{ }^{\circ} \mathrm{C}$ for $6 \mathrm{~h}$ and calcined at $550{ }^{\circ} \mathrm{C}$ for $4 \mathrm{~h}$. The mass concentration of $\mathrm{MoO}_{3}$ and $\mathrm{CoO}$ in each catalyst was $8 \%$ and $2 \%, \mathrm{La}_{2} \mathrm{O}_{3}$ in $\mathrm{CoMo}-\mathrm{La} / \gamma-\mathrm{Al}_{2} \mathrm{O}_{3}$ was $1 \%, \mathrm{Fe}_{2} \mathrm{O}_{3}$ in $\mathrm{CoMo}-\mathrm{Fe} / \gamma-$ $\mathrm{Al}_{2} \mathrm{O}_{3}$ was $1 \%$.

\subsection{Methods}

\subsection{1 $\mathrm{N}_{2}$ physisorption}

$\mathrm{N}_{2}$ adsorption-desorption experiments were performed on a Micromeritics ASAP 2400 equipment. The catalysts sample was evacuated at $300{ }^{\circ} \mathrm{C}$ under vacuum for $5 \mathrm{~h}$.

\subsubsection{HRTEM analysis}

High-resolution transmission electron microscopy (HRTEM) images of the sulfided catalysts were obtained on a Philips Tecnai $G_{2} \quad F_{20}$ Transmission Electron Microscope (Philips Co., Netherlands). The samples were 
prepared by dropping the dispersed suspensions on carbon-coated copper grids.

\subsubsection{XPS analysis}

X-ray photoelectron spectroscopy (XPS) measurements of the sulfided catalysts were obtained using a Thermo Fisher K-Alpha instrument with monochromatic AlK $\alpha$ radiation. Before measurement, the freshly sulfided catalysts were put into cyclohexane to avoid contact with air.

\subsubsection{Sulfidation conditions and catalysts evaluation}

The catalytic of performance of catalysts were evaluated in a continuous flow fixed-bed micro-reactor. $5 \mathrm{ml}$ samples were loaded in a stainless steel tube reactor with internal diameter of $10 \mathrm{~mm}$. Before reaction, the catalysts were presulfided with $2 \mathrm{wt} \% \mathrm{CS}_{2}$ in petroleum ether at $310^{\circ} \mathrm{C}, 1.6 \mathrm{Mpa}$ for $4 \mathrm{~h}$. Then, the FCC gasoline was fed into reactor under the reaction conditions: $240^{\circ} \mathrm{C}, 1.6 \mathrm{MPa}$, liquid hourly volume space velocity (LHSV) of $4.0 \mathrm{~h}^{-1}$ and volumetric ratio of $\mathrm{H}_{2}$ to oil of 300 . The products were collected per $4 \mathrm{~h}$, after a stabilization period of $12 \mathrm{~h}$. The total sulfur content was determined by ANTEK7000NS. The compositions of feed and products were analyzed by SP-3420A GC installed with HP-PONA capillary column.

\section{Results and discussion}

The textural properties of the catalysts are shown in Table 1. It shows that compared with $\mathrm{CoMo} / \gamma-\mathrm{Al}_{2} \mathrm{O}_{3}$ catalysts, the surface area of $\mathrm{CoMo}-\mathrm{La} / \gamma-\mathrm{Al}_{2} \mathrm{O}_{3}$ have decreased and the mean pore diameter have increased significantly, which could attribute to the blockade of small pores by $\mathrm{La}_{2} \mathrm{O}_{3}$ particles [11]. And the CoMo-Fe/ $\gamma-$ $\mathrm{Al}_{2} \mathrm{O}_{3}$ has a little change on surface area and mean pore diameter, which indicate that the $\mathrm{Fe}_{2} \mathrm{O}_{3}$ particles were well dispersed on support. Fig.2 shows the pore size distribution of three catalysts. It can be seen that compared with $\mathrm{CoMo} / \gamma-\mathrm{Al}_{2} \mathrm{O}_{3}$, the most probable diameter of the catalysts modified by $\mathrm{La}$ and $\mathrm{Fe}$ are little smaller.

Table1. Textural properties of the catalysts

\begin{tabular}{cccc}
\hline Catalysts & $\mathrm{S}_{\mathrm{g}}{ }^{\mathrm{a}}\left(\mathrm{m}^{2} / \mathrm{g}\right)$ & $\mathrm{V}_{\mathrm{p}}^{\mathrm{b}}(\mathrm{ml} / \mathrm{g})$ & $\mathrm{D}_{\mathrm{p}}{ }^{\mathrm{c}}(\mathrm{nm})$ \\
\hline $\mathrm{CoMo} / \gamma-\mathrm{Al}_{2} \mathrm{O}_{3}$ & 268.8 & 0.50 & 7.38 \\
$\mathrm{CoMo}-\mathrm{La} / \gamma-\mathrm{Al}_{2} \mathrm{O}_{3}$ & 236.8 & 0.48 & 8.17 \\
$\mathrm{CoMo}-\mathrm{Fe} / \gamma-\mathrm{Al}_{2} \mathrm{O}_{3}$ & 259.3 & 0.49 & 7.58 \\
\hline
\end{tabular}

a BET surface area.

b Pore volume.

c Mean pore diameter

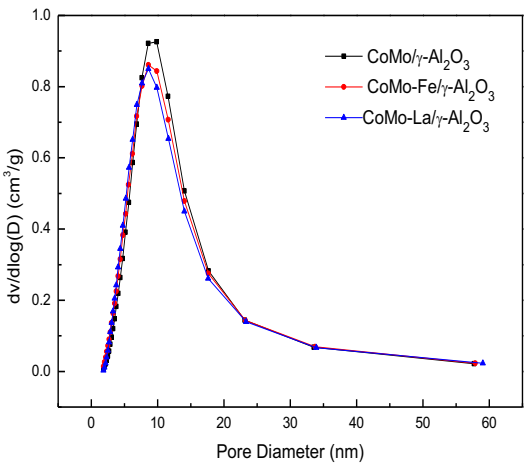

Figure1. Pore size distribution of catalysts

The Mo 3d XPS spectra and their deconvolutions of the three sulfided catalysts are listed in Fig.2. It shows that the spectra contained three Mo 3d doublets and the peak of S 2s about $225.9 \mathrm{eV}$ [12]. According to literature [13], the binding energies at $232.3 \mathrm{eV}$ and $235.4 \mathrm{eV}$ were attributed to $\mathrm{Mo}^{6+}$; the doublet with energies at $228.4 \mathrm{eV}$ and $231.5 \mathrm{eV}$ was related to $\mathrm{Mo}^{4+}$; the last doublet with energies at $230.1 \mathrm{eV}$ and $233.2 \mathrm{eV}$ was attributed to $\mathrm{Mo}^{5+}$. The sulfidation degree of Mo species, denoted as $\mathrm{Mo}_{\text {sulfidation, }}$ was calculated as $\mathrm{Mo}_{\text {sulfidation }}=\mathrm{Mo}^{4+} /\left(\mathrm{Mo}^{4+}+\right.$ $\left.\mathrm{Mo}^{5+}+\mathrm{Mo}^{6+}\right)$ [14]. The results listed in Table 2 show that the $\mathrm{Mo}_{\text {sulfidation }}$ of the three catalysts increasing as CoMo$\mathrm{Fe} / \gamma-\mathrm{Al}_{2} \mathrm{O}_{3}>\mathrm{CoMo}-\mathrm{La} / \gamma-\mathrm{Al}_{2} \mathrm{O}_{3} \mathrm{Mo}>\mathrm{CoMo} / \gamma-\mathrm{Al}_{2} \mathrm{O}_{3}$,

demonstrating the promoting effect of the introduction of $\mathrm{La}$ and $\mathrm{Ce}$. This can be concluded that the $\mathrm{La}$ or Fe incorporation weaken the interaction of active metal phase and support.

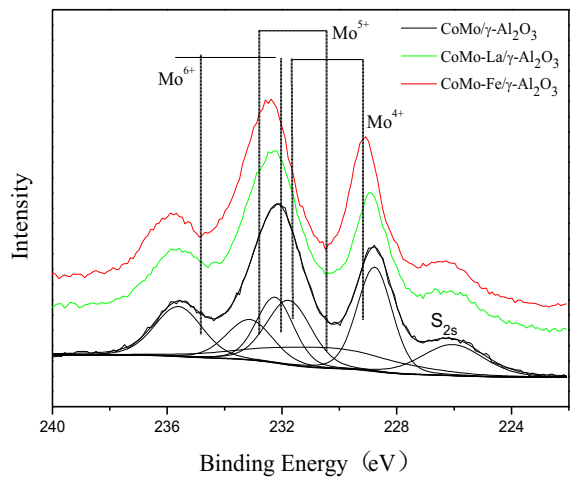

Figure2. Mo 3d XPS spectra of catalysts

Table2. Sulfidation degree of catalysts

\begin{tabular}{cc}
\hline Catalysts & $\mathrm{Mo}_{\text {sulfidation }}(\%)$ \\
\hline $\mathrm{CoMo} / \gamma-\mathrm{Al}_{2} \mathrm{O}_{3}$ & 43.8 \\
$\mathrm{CoMo}-\mathrm{La} / \gamma-\mathrm{Al}_{2} \mathrm{O}_{3}$ & 47.6 \\
$\mathrm{CoMo}-\mathrm{Fe} / \gamma-\mathrm{Al}_{2} \mathrm{O}_{3}$ & 51.3 \\
\hline
\end{tabular}

The representative HRTEM micrographs of three catalysts are provided in Fig.3. It could be seen that the $\mathrm{MoS}_{2}$ slabs structure are well dispersed. The representative HRTEM micrographs of three catalysts are provided in Fig.3. It could be seen that the $\mathrm{MoS}_{2}$ slabs 
structure are well dispersed. Though the statistical analysis, about $400 \mathrm{MoS}_{2}$ slabs from 30 representative micrographs obtained from different part of each sulfided catalyst have been conducted to compare the average length $(\bar{L})$ and stacking layer numbers $(\bar{N})$. The average slab lengths $(\bar{L})$ and stacking layer numbers $(\bar{N})$ were calculated by the following formula[15],

$$
\bar{L}(\bar{N})=\frac{\sum_{i=1}^{n} x_{i} M_{i}}{\sum_{i=1}^{n} x_{i}}
$$

where $M_{i}$ is the slab length or stacking layer number of a $\mathrm{MoS}_{2}$ unit, and $x_{i}$ is the number of slabs or stacks in the determined range of length or stacking number.
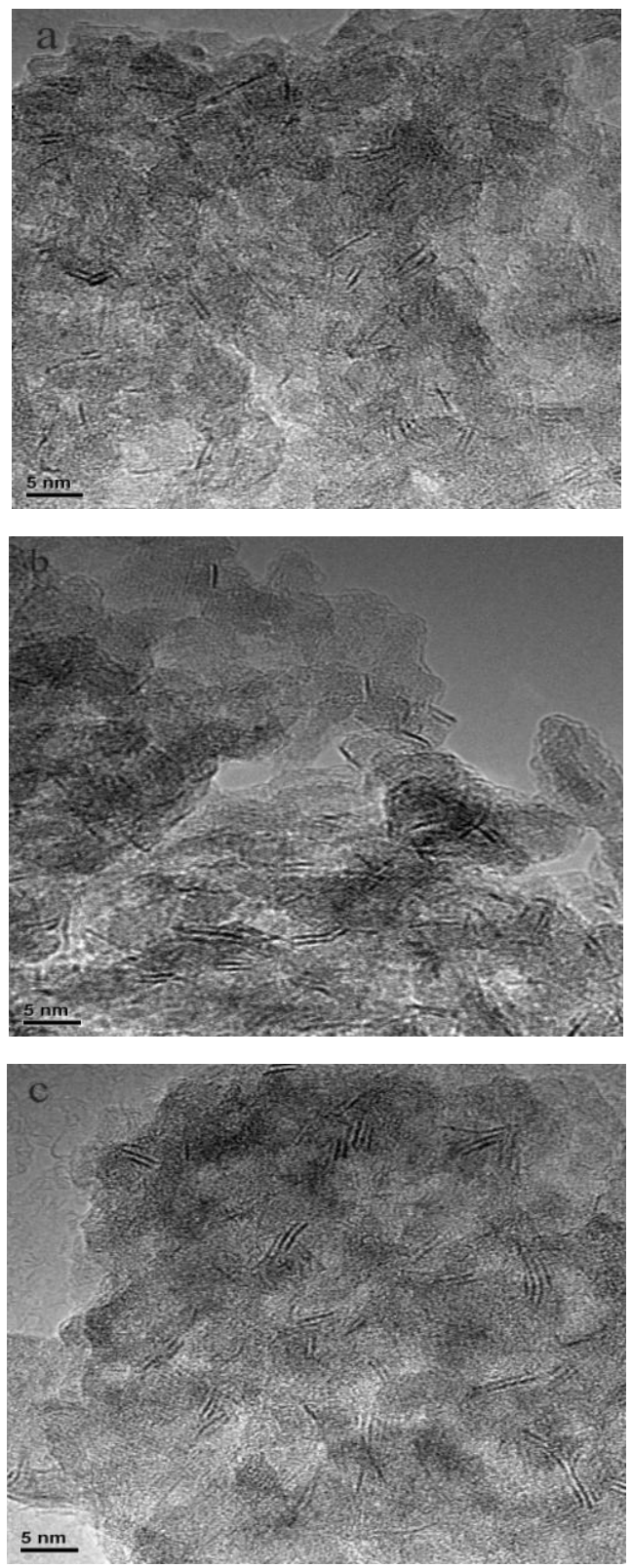

Figure3. HRTEM images of the sulfided catalysts. (a) $\mathrm{CoMo} / \gamma$ $\mathrm{Al}_{2} \mathrm{O}_{3}$, (b) CoMo-La $/ \gamma-\mathrm{Al}_{2} \mathrm{O}_{3}, \mathrm{CoMo}-\mathrm{Fe} / \gamma-\mathrm{Al}_{2} \mathrm{O}_{3}$
The statistical results are listed in Table 3. It is clear that the effects of $\mathrm{La}$ and $\mathrm{Fe}$ incorporation on $\bar{L}$ and $\bar{N}$. Compared with those in $\mathrm{CoMo} / \gamma-\mathrm{Al}_{2} \mathrm{O}_{3}$, the $\mathrm{MoS}_{2}$ slabs in $\mathrm{CoMo}-\mathrm{La} / \gamma-\mathrm{Al}_{2} \mathrm{O}_{3}$ have a longer average length and higher average stacking number. Moreover, CoMo-Fe $/ \gamma$ $\mathrm{Al}_{2} \mathrm{O}_{3}$ has the longest average length and highest average stacking number of $\mathrm{MoS}_{2}$ slabs. This indicated that the introduction of $\mathrm{La}$ or $\mathrm{Fe}$ weaken the interaction of metal and support, which could be consolidated with the results of the XPS characterization.

Table3. Average slab lengths and stacking layer numbers on the sulfided catalysts.

\begin{tabular}{ccc}
\hline Catalysts & $\bar{L}(\mathrm{~nm})$ & $\bar{N}$ \\
\hline $\mathrm{CoMo} / \gamma-\mathrm{Al}_{2} \mathrm{O}_{3}$ & 2.34 & 2.01 \\
$\mathrm{CoMo}-\mathrm{La} / \gamma-\mathrm{Al}_{2} \mathrm{O}_{3}$ & 2.49 & 2.21 \\
$\mathrm{CoMo}-\mathrm{Fe} / \gamma-\mathrm{Al}_{2} \mathrm{O}_{3}$ & 2.58 & 2.34 \\
\hline
\end{tabular}

The catalytic activities of three catalysts for HDS and HYDO were evaluated. The assessment results are given in Table 4. It is shown that both the CoMo- $\mathrm{La} / \gamma-\mathrm{Al}_{2} \mathrm{O}_{3}$ and $\mathrm{CoMo}-\mathrm{Fe} / \gamma-\mathrm{Al}_{2} \mathrm{O}_{3}$ has the better HDS activity, but the HYDO activity of the former increased simultaneously. So, the CoMo-Fe $/ \gamma-\mathrm{Al}_{2} \mathrm{O}_{3}$ catalyst has the best selective HDS activity. Contacted with the results of characterization, the CoMo-Fe $/ \gamma-\mathrm{Al}_{2} \mathrm{O}_{3}$ catalyst has the maximum sulfidation degree of Mo species, longest average length and highest stacking layer numbers.

Table4. HDS and HYDO of the sulfided catalysts.

\begin{tabular}{ccc}
\hline Catalysts & HDS $\%$ & HYDO $\%$ \\
\hline $\mathrm{CoMo} / \gamma-\mathrm{Al}_{2} \mathrm{O}_{3}$ & 94.3 & 16.1 \\
$\mathrm{CoMo}-\mathrm{La} / \gamma-\mathrm{Al}_{2} \mathrm{O}_{3}$ & 95.4 & 16.8 \\
$\mathrm{CoMo}-\mathrm{Fe} / \gamma-\mathrm{Al}_{2} \mathrm{O}_{3}$ & 96.7 & 16.2 \\
\hline
\end{tabular}

\section{Conclusions}

The CoMo $/ \gamma-\mathrm{Al}_{2} \mathrm{O}_{3}$ catalysts modified by $\mathrm{La}$ and $\mathrm{Fe}$ are prepared for selective HDS. These three catalysts haver been characterized by $\mathrm{N}_{2}$ adsorption-desorption, XPS, HRTEM and tested with FCC gasoline. The sulfidation degree of Mo species was improved, with average slab lengths and stacking layer numbers of the $\mathrm{MoS}_{2}$ slabs both increased. The CoMo-Fe $/ \gamma-\mathrm{Al}_{2} \mathrm{O}_{3}$ catalyst has the best activity and optimal morphology among three catalysts.

\section{References}

1. S. Brunet, D. Mey, G. Pérot, C. Bouchy, F. Diehl. Applied Catalysis A: General, 278(2005), 143-172.

2. E. Ito, J.A.R. van Veen. Catalysis Today, 116(2006), 446-460.

3. H. Topsøe. Applied Catalysis A: General, 322(2007), 3-8. 
4. Y. Fan, G. Shi, H. Liu, X. Bao. Applied Catalysis B: Environmental, 91(2009), 73-82

5. P.G. Moses, B. Hinnemann, H. Topsøe, J.K. Nørskov. Journal of Catalysis, 268(2009), 201-208.

6. S. Damyanova, L. Petrov, P. Grange. Applied Catalysis A: General, 239(2003), 241-252.

7. S. Shan, P. Yuan, W. Han, G. Shi, X. Bao. Journal of Catalysis, 330(2015), 288-301

8. V. La Parola, G. Deganello, A.M. Venezia. Applied Catalysis A: General, 260(2004), 237-247.

9. H. Li, M. Li, Y. Chu, F. Liu, H. Nie. Fuel, 116(2014), 168-174.

10. J. Vakros, A. Lycourghiotis, G.A. Voyiatzis, A. Siokou, C. Kordulis. Applied Catalysis B: Environmental, 96(2010), 496-507.

11. T.K.T. Ninh, D. Laurenti, E. Leclerc, M. Vrinat. Applied Catalysis A: General, 487(2014), 210-218.

12. W. Chen, F. Maugé, J. van Gestel, H. Nie, D. Li, X. Long. Journal of Catalysis, 304(2013), 47-62.

13. P.A. Nikulshin, D.I. Ishutenko, A.A. Mozhaev, K.I. Maslakov, A.A. Pimerzin. Journal of Catalysis, 312(2014), 152-169.

14. E.J.M. Hensen, P.J. Kooyman, Y. van der Meer, A.M. van der Kraan, V.H.J. de Beer, J.A.R. van Veen, R.A. van Santen. Journal of Catalysis, 199(2001), 224-235.

15. P.A. Nikulshin, V.A. Salnikov, A.V. Mozhaev, P.P. Minaev, V.M. Kogan, A.A. Pimerzin. Journal of Catalysis, 309(2014), 386-396. 